•编者按・

\title{
新时期植物园的机遇和挑战
}

\author{
${\text { 龙春林 }{ }^{1 *} \text { 马克平 }}^{2}$ \\ 1 (中央民族大学生命与环境科学学院, 北京 100081) \\ 2 (中国科学院植物研究所植被与环境变化国家重点实验室, 北京 100093)
}

\section{Challenges and opportunities for botanical gardens in a new era}

\author{
Chunlin Long ${ }^{1 *}$, Keping $\mathrm{Ma}^{2}$ \\ 1 College of Life and Environmental Sciences, Minzu University of China, Beijing 100081 \\ 2 State Key Laboratory of Vegetation and Environmental Change, Institute of Botany, Chinese Academy of Sciences, Bei- \\ jing 100093
}

1876年，英国皇家植物园邱园(The Royal Botanic Gardens, Kew, 简称邱园)将三叶橡胶(Hevea brasiliensis)幼苗送至英国在南亚、东南亚的殖民地 试种, 这些幼苗是邱园用从南美洲引种获得的种子 繁殖出来的。橡胶在东南亚试种获得成功后, 发展 成为庞大的橡胶产业，对全世界的工业、农业、交 通运输、经济、社会乃至政治产生了极大的影响, 也 使得橡胶成为一种“改变世界历史进程”的植物 (Laws, 2010)。这是植物园重要性的一个典型案例。

植物园的角色多种多样, 承担着科学研究、植物 多样性保护和可持续利用、科学普及、休闲娱乐和 文化传播等重要功能, 并随着时代发展而渐渐演变。 在人口持续增加、耕地面积减少、植被锐减和生态 系统退化的困境面前, 植物园将在未来发挥越来越 重要的作用, 不仅能为植被恢复做出贡献(Miller et al, 2016), 为环境保护提供对策(Qumsiyeh, 2017), 对 保障粮食安全也意义重大(Miller et al, 2015)。

邱园继2016年发布全球植物现状报告(State of the World's Plants Report)之后, 今年又发布2017年 度报告, 引起了轰动。这确实是世界科技界的又一 件大事, 不仅提出了科学家和公众非常关心的一些 重大问题, 而且给出了权威的、基于海量数据和最 新研究成果的答案。

全球植物现状报告(也可翻译成世界植物现状 报告) 是由邱园会同世界各地约80位科学家针对全 球植物现状做出的高度概括和总结 (RBG Kew,
2016，2017)。这两份年度报告的要点是：全世界已 知的维管植物有452科391,000种, 2015年和2016年 分别发现 2,034 个和 1,750 个新种, 菊科、兰科和豆科 分别以31,581种、28,237种和20,856种获得植物界的 冠军、亚军和季军; 世界上目前记载了31,128种有 用植物，其中 28,787 种为药用植物; 全球 $1 / 5$ 的植物 物种面临灭绝的风险, 有30,000余种受《濒危野生 动植物种国际贸易公约》(CITES)保护; 约106,700 种植物至少有 1 个DNA片段保存于基因库, 已完成 了其中139种植物的全基因组测序; 认定了 1,771处 全球重要的植物分布区, 但世界植物正受到森林面 积锐减、全球气候变化、植物病害等严重影响, 记 录在案的入侵植物已达6,075种(RBG Kew，2016, 2017)。

邱园未来3年将继续针对全球植物的科研、保 护、科普、公众和社会服务等方面做出世界级贡献。 例如, 通过网络提供世界已知种子植物的在线信息, 收集种类占世界种子植物 $25 \%$ 的种子保存于千年种 子库(The Millennium Seed Bank), 将80\%的馆藏标 本数字化, 发表 1,800 篇论著和研究报告, 每年为 300万名游客提供数字资源(https://www.kew.org/)。 很多著名植物园, 如纽约植物园、密苏里植物园、 墨尔本植物园、莱顿植物园等, 也与邱园一样, 承 载着全球植物园的使命, 引领着世界植物园的发展 方向。我国一些大的植物园包括中国科学院的几个 植物园也在朝着这个方向努力。

\footnotetext{
* 通讯作者 Author for correspondence. E-mail: long.chunlin@muc.edu.cn
} 
然而, 关于植物园的使命、功能、发展定位, 历 来是仁者见仁、智者见智。全球3,300多个植物园的 历史、地理、政治、经济、文化等千差万别, 任务 和使命也各不相同, 大多数植物园都在某一个或某 些方面有所侧重, 像邱园这样的全功能植物园是比 较少的。

中国的植物园迎来了最好的发展时期, 全国各 地不断建新园, 数量已接近 200 个, 南京中山植物 园和庐山植物园等老的植物园焕发生机, 深圳仙湖 植物园、上海辰山植物园等新兴的植物园异军突起, 欣欣向荣, 在全球植物园界独树一帜。诚然, 我们 也要看到, 中国植物园正处于大发展的十字路口。

《生物多样性》2016年第6期发表了洪德元院 士的短文 “三个“哪些”：植物园的使命”, 引起读者 的广泛关注, 期刊自建网站的下载量已达 7,946次 (http://www.biodiversity-science.net/article/2016/1005 -0094-24-6-728.html, 2017年9月26日检索), 排在 1993年创刊以来发表文章下载排行的第6位。在本 期的“植物园定位与发展战略专题” 中, 洪德元院士 对植物园的定位发表了新的认识(洪德元, 2017), 许 再富(2017)、贺善安和顾姻(2017)等老一辈科学家, 根据多年来积累的丰富经验也提出了自己的见解。 黄宏文(2017)、任海(2017)、胡永红等(2017)当代植 物园领域的中坚力量, 通过自己的切身体会阐述了 植物园新的功能和作用。刘华杰(2017)站在博物学 立场, 从不同的角度描绘了不一样的植物园。他们 的见解和思考对中国植物园的定位和发展颇有裨 益, 对世界植物园的建设也有借鉴作用。

植物园从一开始就是与产业发展相关联的, 从
最早帕多瓦植物园栽培的药用植物, 到引种和推广 橡胶的邱园, 再到大型植物园长期以来设立的经济 植物学研究所、民族植物学研究所或此类专业团队, 无不注重植物的有效利用和社会经济的可持续发 展。植物的引种、驯化、收集和应用研究, 仍将是 植物园今后发展的重要方向。

植物、植物园与文化之间存在着不可分割的关 系, 没有文化底蕴的植物园, 只是植物体的堆砌, 不会具有植物园的灵魂, 也很难真正引起公众的浓 厚兴趣。植物园是具有地域性的, 如果与当地民族 传统文化构建成一个有机的整体, 不仅能深深地吸 引当地民众, 而且能在世界植物园之中争得一席之 地。游客在亲近植物、休闲娱乐的游园过程中，体 验其中的民族传统文化内涵, 那么植物园也就成为 了民族文化传播的载体。

改革开放为中国植物园走向世界提供了前所 未有的机遇。目前我国实施的“走出去”战略, 特别 是中国科学院的植物园(如武汉植物园、华南植物 园、西双版纳热带植物园等)与非洲、南美洲和东南 亚开展合作，必将对今后中国植物园的发展产生深 远的影响。伴随着“一带一路”的推进, 中国的植物 园也将与沿线国家的植物园建立广泛的实质性合 作关系, 实现合作共赢, 推动中国的植物园走向世 界, 成为全球植物园网络的重要成员和领导者。

文中引用的文献见附录1 (http://www.biodiversity-science.net/fileup/PDF/2017257-1.pdf)。

(责任编辑: 周玉荣) 